\title{
Inhibition of Sporulation in Bacillus subtilis by Bromodeoxyuridine and the Effect on DNA Replication
}

\author{
By C. BINNIE† AND J. G. COOTE* \\ Microbiology Department, University of Glasgow, Garscube Estate, Bearsden, \\ Glasgow G61 1QH, UK
}

(Received 7 May 1985; revised 4 September 1985)

\begin{abstract}
A 5-bromo-2'-deoxyuridine (BUdR)-tolerant derivative of a thymidine ( $T d R)$-requiring strain of Bacillus subtilis was used to examine the effect of BUdR, an analogue of TdR, on sporulation. At a TdR:BUdR ratio which had little effect on growth, sporulation was inhibited if cells were exposed to BUdR during the period of DNA synthesis at the onset of the process. Cells recovered from BUdR inhibition of sporulation if the analogue was removed and DNA replication allowed to continue with TdR alone. BUdR prolonged the period of DNA synthesis during sporulation and experiments with chloramphenicol suggested that this was due in part to unscheduled initiation of new rounds of replication.
\end{abstract}

\section{INTRODUCTION}

In many eukaryotic cells the thymidine ( $\mathrm{TdR}$ ) analogue 5-bromo-2'-deoxyuridine (BUdR) selectively affects processes associated with differentiation without a significant effect on cell growth or overall RNA and protein synthesis (Rutter et al., 1973). In most cases BUdR prevents the expression of differentiated functions (Stockdale et al., 1964; Levitt \& Dorfman, 1972), but in a few instances it induces or activates differentiation associated functions in growing cells (Schubert \& Jacob, 1970; Koyama \& Ono, 1972; Biswas et al., 1979). It has proved difficult to propose a general hypothesis to account for the range of effects that the analogue has on differentiation in eukaryotes, but generally a correlation exists between the effects on differentiation and the extent of incorporation of BUdR into DNA in place of TdR. Thus, sensitivity to the analogue usually occurs during a restricted period of development when DNA replication is in progress (Weintraub et al., 1972; Mayne et al., 1973; Lough \& Bischoff, 1976; O'Brien, 1980) and inhibition of differentiation is reversible if DNA replication occurs in the absence of the analogue (Miura \& Wilt, 1971). In some experimental systems, however, particularly those using cartilage cells, recovery from BUdR suppression of differentiation has not been uniformly obtained (Levitt \& Dorfman, 1972; Conway et al., 1982). In other instances, a reversal of BUdR inhibition of differentiation has been noted without an accompanying alteration in the BUdR content of DNA (Schubert \& Jacob, 1970; Davidson \& Kaufmann, 1977; Reff \& Davidson, 1979). An explanation of the action of BUdR via alterations in transcription has been suggested (Hill et al., 1974; Lin et al., 1976; Gordon et al., 1976; Garcia et al., 1981), but BUdR can alter the surface properties and membrane fluidity of cells (Evans $e t$ al., 1977; Rosenthal et al., 1978) and it is not clear if this is a direct effect of BUdR or a consequence of its incorporation into DNA.

† Present address: Genetics Department, University of Glasgow, Church Street, Glasgow G11 5JS, UK.

Abbreviations: TdR, thymidine; BUdR, 5-bromo-2'-deoxyuridine; HPUra, 6-( $p$-hydroxyphenylazo)uracil, U, uridine, $\mathrm{dC}$, deoxycytidine; $\mathrm{SM}$, starvation medium; $\mathrm{CH}$, casein hydrolysate. 
Endospore formation in bacteria can be regarded as a primitive form of cellular differentiation. The process is controlled to a great extent by activation of genes which remain repressed during vegetative growth (Piggot \& Coote, 1976; Losick \& Pero, 1981; Johnson et al., 1983). Coote (1977) showed that treatment of a TdR-requiring BUdR-tolerant strain of $B$. subtilis with BUdR, at concentrations which had little effect on growth, markedly reduced the sporulation capacity of the cells. The work reported here indicates that the inhibitory effect of BUdR on sporulation is associated with an alteration in the normal pattern of DNA synthesis which occurs during the early stages of the process. Some of this work was presented earlier in preliminary form (Coote \& Binnie, 1981).

\section{METHODS}

Strains. Bacillus subtilis (thy A thy B but-32) is described in the accompanying paper (Coote \& Binnie, 1986). B. subtilis (thy $A$ thy $B$ trpC2 dnaBI34 but-32) was isolated on minimal agar supplemented with L-tryptophan $\left(10 \mu \mathrm{g} \mathrm{ml}^{-1}\right)+\mathrm{TdR}\left(1 \mu \mathrm{g} \mathrm{ml}^{-1}\right)+\mathrm{BUdR}\left(20 \mu \mathrm{g} \mathrm{ml}^{-1}\right)$ after transformation of strain Tsl $34(\operatorname{thy} A \operatorname{thy} B \operatorname{trp} C 2$ dnaB 134) with DNA prepared from strain BUt32 (thy $A$ thy $B$ but-32). Strains harbouring the dnaB134 mutation are temperature-sensitive for the initiation of chromosome replication. At the restrictive temperature $\left(46^{\circ} \mathrm{C}\right)$ replication in progress is completed, but new rounds of replication are not initiated (Mendelson \& Gross, 1967).

Growth and sporulation. A sample from an overnight culture grown at $35^{\circ} \mathrm{C}$ with shaking in $20 \mathrm{ml}$ casein hydrolysate $(\mathrm{CH})$ medium (Sterlini \& Mandelstam, 1969) supplemented with $\mathrm{TdR}\left(8.5 \mu \mathrm{g} \mathrm{ml}^{-1}\right)$ or $\mathrm{TdR}^{\mathrm{N}}$ $\left(1 \mu \mathrm{g} \mathrm{m}^{-1}\right)+$ BUdR $\left(15 \mu \mathrm{g} \mathrm{ml}^{-1}\right)$ was passed through a membrane filter (Oxoid, $0.45 \mu \mathrm{m}$ pore size) washed with prewarmed $\left(35^{\circ} \mathrm{C}\right) \mathrm{CH}$ medium and resuspended in fresh $\mathrm{CH}$ medium, plus the necessary additions, to give an $\mathrm{OD}_{600}$ of $0 \cdot 05$ to $0 \cdot 1$. Growth was measured spectrophotometrically at $600 \mathrm{~nm}$ using a $1 \mathrm{~cm}$ light path. Sporulation was obtained by centrifugation of exponentially growing cells from $\mathrm{CH}$ medium at an $\mathrm{OD}_{600}$ of 0.6 to 0.8 and resuspension of the cells in a starvation medium (SM) containing L-glutamate and inorganic ions plus the necessary auxotrophic requirements (Sterlini \& Mandelstam, 1969). Viable cells were estimated by dilution and plating on nutrient agar (Oxoid). Spore incidence was determined in the same way after heating a sample at $85^{\circ} \mathrm{C}$ for $15 \mathrm{~min}$.

Measurement of DNA synthesis. Incorporation of radiolabelled TdR into acid-insoluble material was determined by the procedure described in the accompanying paper (Coote \& Binnie, 1986) using either $\left[2-{ }^{14} \mathrm{C}\right] \mathrm{TdR}$ [54 $\mathrm{Ci} \mathrm{mmol}^{-1}(1 \mathrm{Ci}=37 \mathrm{GBq})$, Amersham] or $\left[\right.$ methyl $\left.{ }^{3} \mathrm{H}\right] \mathrm{TdR}\left(47 \mathrm{Ci} \mathrm{mmol}^{-1}\right.$, Amersham $)$ as the radiolabel.

Marker frequency analysis. This was done as described in the accompanying paper (Coote \& Binnie, 1986).

Inhibitors. 6-(p-Hydroxyphenylazo)uracil (HPLra) was a gift from B. Langley, ICI, Runcorn, UK. BUdR and chloramphenicol were from Sigma.

\section{RESULTS}

\section{Effect of BUdR on sporulation}

Strain BUt32 grew normally with a BUdR:TdR ratio of between 7.5 and 15:1.0 (Coote \& Binnie, 1986). It was grown and induced to sporulate under conditions where BUdR was either included in the growth medium (CH) or the resuspension medium (SM) or in both (Table 1). No effect on sporulation was observed if the analogue was included in the growth medium but omitted from the resuspension medium. Inclusion of BUdR in the resuspension medium, but not

\section{Table 1. Effect of BUdR on sporulation}

Parallel cultures of strain BUt 32 were grown in $50 \mathrm{ml} \mathrm{CH}$ with the additions shown. Mid-exponential phase cells were centrifuged and resuspended in $50 \mathrm{ml} \mathrm{SM}$ with the additions shown. The spore incidence was determined $20 \mathrm{~h}$ after resuspension.

$$
\begin{aligned}
& \text { Additions to } \\
& \text { growth medium }
\end{aligned}
$$

$\operatorname{TdR}\left(1 \mu \mathrm{g} \mathrm{ml}^{-1}\right)$

$\operatorname{TdR}\left(8 \cdot 5 \mu \mathrm{g} \mathrm{ml}^{-1}\right)$

$\operatorname{TdR}\left(1 \mu \mathrm{g} \mathrm{ml}^{-1}\right)+\mathrm{BUdR}\left(15 \mu \mathrm{g} \mathrm{ml}^{-1}\right)$

$\operatorname{TdR}\left(8.5 \mu \mathrm{g} \mathrm{ml}^{-1}\right)$

$\operatorname{TdR}\left(1 \mu \mathrm{g} \mathrm{ml}^{-1}\right)+$ BUdR $\left(15 \mu \mathrm{g} \mathrm{ml}^{-1}\right)$
Additions to sporulation medium

$\operatorname{TdR}\left(1 \mu \mathrm{g} \mathrm{ml}^{-1}\right)$

$\operatorname{TdR}\left(8.5 \mu \mathrm{g} \mathrm{ml}^{-1}\right)$

$\operatorname{TdR}\left(8.5 \mu \mathrm{g} \mathrm{ml}^{-1}\right)$

$\operatorname{TdR}\left(1 \mu \mathrm{g} \mathrm{ml}^{-1}\right)+\operatorname{BUdR}\left(15 \mu \mathrm{g} \mathrm{ml}^{-1}\right)$

$\operatorname{TdR}\left(1 \mu \mathrm{g} \mathrm{ml}^{-1}\right)+\operatorname{BUdR}\left(15 \mu \mathrm{g} \mathrm{ml}^{-1}\right)$

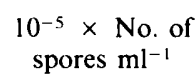

690

750

756

7

1 


\section{Table 2. Effect of uridine and deoxycytidine on BUdR inhibition of sporulation}

Strain BUt32 was grown in $120 \mathrm{ml} \mathrm{CH}+\mathrm{TdR}\left(8.5 \mu \mathrm{g} \mathrm{m}^{-1}\right)$. The cells were harvested from six equal portions of the culture during mid-exponential growth and each portion resuspended in $20 \mathrm{ml} \mathrm{SM}$ with the additions shown. Spore incidence was determined $20 \mathrm{~h}$ after resuspension.

Additions to SM

$\operatorname{TdR}\left(8 \cdot 5 \mu \mathrm{g} \mathrm{ml}^{-1}\right)$

$\operatorname{TdR}\left(1 \mu \mathrm{g} \mathrm{ml}^{-1}\right)+\operatorname{BUdR}\left(15 \mu \mathrm{g} \mathrm{ml}^{-1}\right)$

$\operatorname{TdR}\left(1 \mu \mathrm{g} \mathrm{ml}^{-1}\right)+\operatorname{BUdR}\left(15 \mu \mathrm{g} \mathrm{ml}^{-1}\right)+\mathrm{dC}\left(15 \mu \mathrm{g} \mathrm{ml}^{-1}\right)$

$\operatorname{TdR}\left(1 \mu \mathrm{g} \mathrm{ml}^{-1}\right)+\operatorname{BUdR}\left(15 \mu \mathrm{g} \mathrm{ml}^{-1}\right)+\mathrm{dC}\left(50 \mu \mathrm{g} \mathrm{ml}^{-1}\right)$

$\operatorname{TdR}\left(1 \mu \mathrm{g} \mathrm{m}^{-1}\right)+\operatorname{BUdR}\left(15 \mu \mathrm{g} \mathrm{ml}^{-1}\right)+\mathrm{U}\left(15 \mu \mathrm{g} \mathrm{ml}^{-1}\right)$

$\operatorname{TdR}\left(1 \mu \mathrm{g} \mathrm{m}^{-1}\right)+\operatorname{BUdR}\left(15 \mu \mathrm{g} \mathrm{ml}^{-1}\right)+\mathrm{U}\left(50 \mu \mathrm{g} \mathrm{ml}^{-1}\right)$

$$
\begin{aligned}
& 10^{-4} \times \text { No. of } \\
& \text { spores } \mathrm{ml}^{-1}
\end{aligned}
$$
1500
130
162
150
90
144

in the growth medium, typically reduced the spore incidence to around $1 \%$ of that obtained in the presence of $T d R$ alone. This could reproducibly be further reduced if cells were grown for several generations in the presence of BUdR before resuspension in SM containing BUdR.

The low incidence of sporulation obtained with BUdR was not due to loss of cell viability. Viable cell numbers were similar in cells induced to sporulate with BUdR or TdR alone and did not decline up to $7 \mathrm{~h}$ after resuspension (Coote, 1977; Coote \& Binnie, 1981; Binnie, 1982).

\section{Effect of uridine $(U)$ and deoxycytidine $(d C)$ on BUdR inhibition of sporulation}

Inclusion of excess $U$ in SM did not prevent the inhibitory action of BUdR on sporulation (Table 2). It was unlikely therefore that BUdR exerted its inhibitory action via incorporation into RNA. In support of this assumption, BUdR had no effect on the rate of RNA synthesis, measured as the rate of incorporation of $\left[{ }^{3} \mathrm{H}\right] \mathrm{U}$ into acid-insoluble material, either during growth of strain BUt32 (Coote \& Binnie, 1986) or during the initial $2 \mathrm{~h}$ after resuspension of cells in SM (results not shown).

$\mathrm{dC}$ has, in some instances, been shown to reverse the suppression of differentiation by BUdR in eukaryotic cells (Rogers et al., 1975; Horn \& Davidson, 1976; Davidson \& Kaufmann, 1977). It did not alter the inhibitory effect of BUdR on sporulation in B. subtilis (Table 2). Exogenous $\mathrm{dC}$ can be converted to deoxyuridine nucleotides in $B$. subtilis (Rima \& Takahashi, 1978) which would serve as substrates for synthesis of thymidine nucleotides by thymidylate synthase. In the absence of this enzyme activity in thy $A$ thy $B$ strains, no conversion of $\mathrm{dC}$ to thymidine nucleotides would occur to dilute the intracellular pool of BUdR.

\section{Effect of BUdR on DNA replication during sporulation}

The incorporation of radiolabelled $\mathrm{TdR}$ into acid-insoluble material was compared after but32 cells grown with $\mathrm{TdR}\left(1 \mu \mathrm{g} \mathrm{ml}^{-1}\right)$ were resuspended in $\mathrm{SM}+\mathrm{TdR}\left(1 \mu \mathrm{g} \mathrm{ml}^{-1}\right)$ or SM $+\mathrm{TdR}$ $\left(1 \mu \mathrm{g} \mathrm{ml}^{-1}\right)+\mathrm{BUdR}\left(15 \mu \mathrm{g} \mathrm{ml}^{-1}\right)$. A typical experiment (Fig. $\left.1 a\right)$ showed that cells induced to sporulate with $T d R$ alone incorporated the radiolabel over an initial $4 \mathrm{~h}$ period, but thereafter incorporation ceased. Cells resuspended with BUdR incorporated radiolabel continuously for at least $7 \mathrm{~h}$ after resuspension. The rate of $\mathrm{TdR}$ incorporation in the BUdR medium was slower than in medium with $T d R$ alone, although this could be partly accounted for by the 20 to $22 \%$ substitution of TdR by unlabelled BUdR in the DNA during replication (Binnie, 1982; Binnie \& Coote, 1983).

It was shown that introduction of 5-bromouracil into the DNA of a TdR-requiring strain of $B$. subtilis made the DNA more susceptible to single-strand breaks (Hutchinson \& Hales, 1970). It was conceivable that incorporation of BUdR into the DNA of strain BUt32 during sporulation may have promoted repair synthesis to cope with any damage to the DNA. The prolonged DNA synthesis in the presence of BUdR may thus have been due to repair synthesis rather than normal semi-conservative replication. HPUra has been shown to be a selective inhibitor of semi-conservative replication in $B$. subtilis; repair synthesis was refractory to the action of this drug (Brown, 1970, 1971). Treatment with HPUra of cells undergoing DNA synthesis in the 


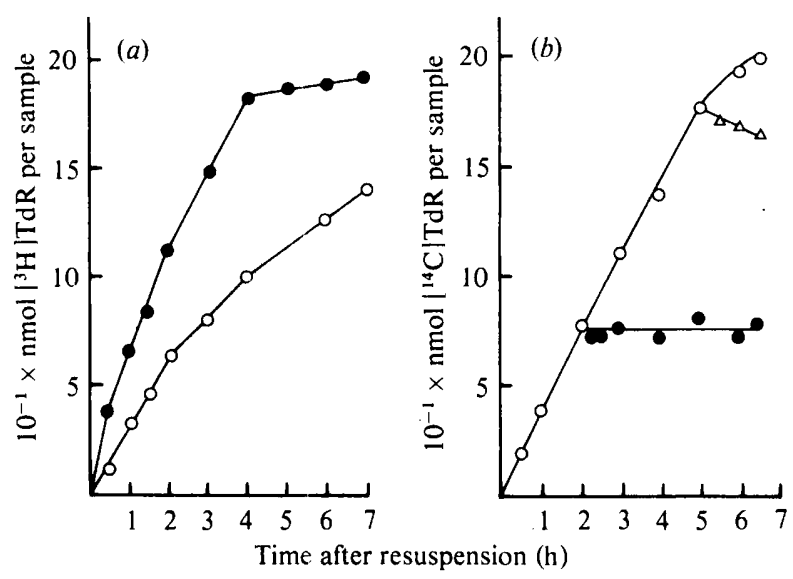

Fig. 1. Incorporation of radiolabelled $\mathrm{TdR}$ into acid-insoluble material during sporulation of strain BUt32. (a) Cells were grown in $50 \mathrm{ml} \mathrm{CH}+\mathrm{TdR}\left(1 \mu \mathrm{g} \mathrm{ml}^{-1}\right)$; one half of the culture was resuspended in $\mathrm{SM}+\operatorname{TdR}\left(1 \mu \mathrm{g} \mathrm{ml}^{-1}\right)+\left[\right.$ methyl $\left.^{-3} \mathrm{H}\right] \mathrm{TdR}\left(0.5 \mu \mathrm{Ci} \mathrm{m}^{-1}\right)(\mathrm{O})$ and the other half in $\mathrm{SM}+\mathrm{TdR}$ $\left(1 \mu \mathrm{g} \mathrm{ml}^{-1}\right)+\mathrm{BUdR}\left(15 \mu \mathrm{g} \mathrm{ml}^{-1}\right)+\left[\right.$ methyl- $\left.{ }^{3} \mathrm{H}\right] \mathrm{TdR}\left(0.5 \mu \mathrm{Ci} \mathrm{m}^{-1}\right)(\mathrm{O}) .($ b $)$ Cells were grown in $60 \mathrm{ml}$ $\mathrm{CH}+\operatorname{TdR}\left(8 \cdot 5 \mu \mathrm{g} \mathrm{ml}^{-1}\right)$ and resuspended in SM $+\mathrm{TdR}\left(1 \mu \mathrm{g} \mathrm{ml}^{-1}\right)+\operatorname{BUdR}\left(15 \mu \mathrm{g} \mathrm{ml}^{-1}\right)+[2-$ $\left.{ }^{1+} \mathrm{C}\right] \mathrm{TdR}\left(0 \cdot 1 \mu \mathrm{Ci} \mathrm{ml}^{-1}\right)$. At $2 \mathrm{~h}$ and $5 \mathrm{~h}$ after resuspension, $20 \mathrm{ml}$ portions of the culture were removed; HPUra was then added to a final concentration of $50 \mu \mathrm{g} \mathrm{ml}^{-1}$ and incubation was continued. $O$, No HPUra addition; - HPUra added after $2 \mathrm{~h} ; \triangle$, HPUra added after $5 \mathrm{~h}$. TdR incorporated was calculated from the specific activity of $T d R$ in the media.

presence of BUdR immediately blocked any further incorporation of $\left[\right.$ methyl $\left.-{ }^{3} \mathrm{H}\right] \mathrm{TdR}$ (Fig. $1 b$ ). It was concluded that the prolonged DNA synthesis observed in the presence of BUdR was due to continued chromosome replication.

\section{Escape from HPUra inhibition of sporulation}

HPUra had been used previously to show that successful formation of spores depended on the completion of chromosome replication in the starvation medium (Dunn et al., 1978). Spores contain completed chromosomes (Oishi et al., 1964; Sargent, 1980), and it is assumed that all replicating forks present in chromosomes proceed to termination before or during packaging of the DNA into the spore. Once replication has gone to completion, addition of the DNA synthesis inhibitor no longer affects the capacity of the cells to sporulate.

A typical experiment (Fig. 2) involving addition of HPUra at intervals to portions of a culture of strain BUt32 induced to sporulate in TdR medium showed that cells began to overcome the inhibitory effect of the drug between 4 and $6 \mathrm{~h}$ after initiation, which correlated with the point during sporulation when DNA synthesis ceased in TdR medium (Fig. 1 a). Transfer of portions of the same culture to $T d R+B U d R$ medium showed that the pattern of escape from BUdR inhibition of sporulation was similar to that from HPUra inhibition, except that cells overcame BUdR inhibition of sporulation somewhat earlier than HPUra inhibition (Fig. 2). Cells grown and resuspended in TdR + BUdR medium showed a delayed escape from HPUra inhibition of sporulation and were only beginning to gain a capacity to sporulate some $7 \mathrm{~h}$ after resuspension in SM. This prolonged inhibition of sporulation by HPUra was in keeping with the extended DNA synthesis found in cells induced to sporulate with BUdR (Fig. 1 $a, b$ ).

\section{Recovery from BUdR inhibition of sporulation}

Previous work had shown that cells prevented from sporulating in the presence of BUdR could regain their sporulation capacity if the analogue was removed from SM and replaced by TdR (Coote, 1977). This recovery in sporulation capacity did not occur if DNA synthesis was prevented by treatment of cells with HPUra or starvation for TdR. For example, in an experiment similar to that described in Fig. 2, strain BUt32 was grown and resuspended in 


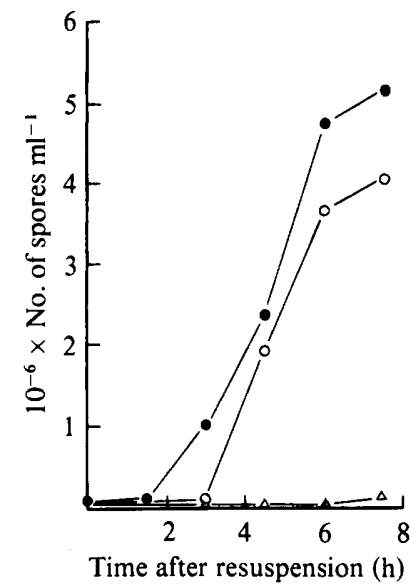

Fig. 2. Escape of strain BUt32 from HPUra and BUdR inhibition of sporulation. Two separate cultures were grown and resuspended in media containing (i) $\mathrm{TdR}\left(8.5 \mu \mathrm{g} \mathrm{ml}^{-1}\right)$ or (ii) $\mathrm{TdR}\left(1 \mu \mathrm{g} \mathrm{ml}^{-1}\right)$ + BUdR $\left(15 \mu \mathrm{g} \mathrm{ml}^{-1}\right)$. At intervals after resuspension, two $10 \mathrm{ml}$ portions were removed from culture (i); one was treated with HPUra $\left(50 \mu \mathrm{g} \mathrm{ml}^{-1}\right)(\mathrm{O})$ and cells of the other were collected on a membrane filter and washed and resuspended in $10 \mathrm{ml} \mathrm{SM}+\mathrm{TdR}\left(1 \mu \mathrm{g} \mathrm{ml}^{-1}\right)+\mathrm{BUdR}\left(15 \mu \mathrm{g} \mathrm{ml}^{-1}\right)(O)$. At the same sampling times, a $10 \mathrm{ml}$ portion was removed from culture (ii) and treated with HPUra $\left(50 \mu \mathrm{g} \mathrm{ml}^{-1}\right)(\triangle)$. The number of heat-resistant spores was determined in each culture $20 \mathrm{~h}$ after resuspension.

media containing $\mathrm{TdR}\left(1 \mu \mathrm{g} \mathrm{ml}^{-1}\right)+\mathrm{BUdR}\left(15 \mu \mathrm{g} \mathrm{ml}^{-1}\right) ; 3 \mathrm{~h}$ after resuspension, eight $10 \mathrm{ml}$ samples were taken and the cells of each were collected on a membrane filter and washed and resuspended in SM; one in SM alone, one with added TdR $\left(8.5 \mu \mathrm{g} \mathrm{ml}^{-1}\right)+\operatorname{HPUra}\left(50 \mu \mathrm{g} \mathrm{ml}^{-1}\right)$ and the others in TdR $\left(8.5 \mu \mathrm{g} \mathrm{ml}^{-1}\right)$. HPUra $\left(50 \mu \mathrm{g} \mathrm{ml}^{-1}\right)$ was added to five of the latter samples at intervals after transfer to $T d R$ medium. Spore incidence, determined $20 \mathrm{~h}$ after resuspension, was $6,4,5,8$ and 7 spores $\mathrm{ml}^{-1}\left(\times 10^{-4}\right)$ for cells deprived of $\mathrm{TdR}$ or exposed to HPUra at 0 , 10,20 and $40 \mathrm{~min}$ respectively. Spore incidence increased to 17 and 61 spores $\mathrm{ml}^{-1}\left(\times 10^{-4}\right)$ in cells exposed to HPUra at 60 and 90 min respectively. Spore incidence in celis given TdR only was $>500$ spores $\mathrm{ml}^{-1}\left(\times 10^{-4}\right)$. Thus, at least $60 \mathrm{~min}$ in the presence of $\mathrm{TdR}$ alone was required before the cells began to regain sporulation capacity. This delay was not caused by a lag in DNA synthesis as incorporation of $\left[{ }^{3} \mathrm{H}\right] \mathrm{TdR}$ into acid-insoluble material continued normally after replacement of BUdR medium by TdR containing SM medium (Coote \& Binnie, 1981).

\section{$D N A$ replication after addition of chloramphenicol}

Chloramphenicol allows the completion of existing rounds of replication, but prevents the initiation of new rounds (Lark et al., 1963). The drug was added to portions of a culture of strain BUt32 grown and resuspended with TdR alone. A typical experiment (Fig. $3 a$ ) showed that exposure of cells to chloramphenicol 2 and $4 \mathrm{~h}$ after initiation had essentially no effect on the pattern of DNA synthesis. Inclusion of the drug at the point of resuspension, however, allowed DNA synthesis to continue for only about $90 \mathrm{~min}$ before incorporation of radiolabel ceased at a level roughly half of that achieved in the control cells. This suggested that during the initial $2 \mathrm{~h}$ after resuspension, most cells initiated a new round of replication and this was prevented by addition of chloramphenicol at the point of resuspension. Cells grown and resuspended with BUdR were still undergoing DNA synthesis $7.5 \mathrm{~h}$ after initiation (Fig. $3 \mathrm{~b}$ ). Again, exposure of cells to chloramphenicol at the point of resuspension only allowed DNA synthesis to continue for about $120 \mathrm{~min}$ before it ceased at a plateau value slightly below that of cells using TdR alone. This would be expected, due to the replacement of a fraction of the $\mathrm{TdR}$ residues with unlabelled BUdR (Coote \& Binnie, 1986). When chloramphenicol was added $2 \mathrm{~h}$ after resuspension, DNA synthesis slowed down markedly about $4 \mathrm{~h}$ after initiation, although it did not appear to cease completely. Chloramphenicol added $4 \mathrm{~h}$ after resuspension allowed DNA synthesis to continue 


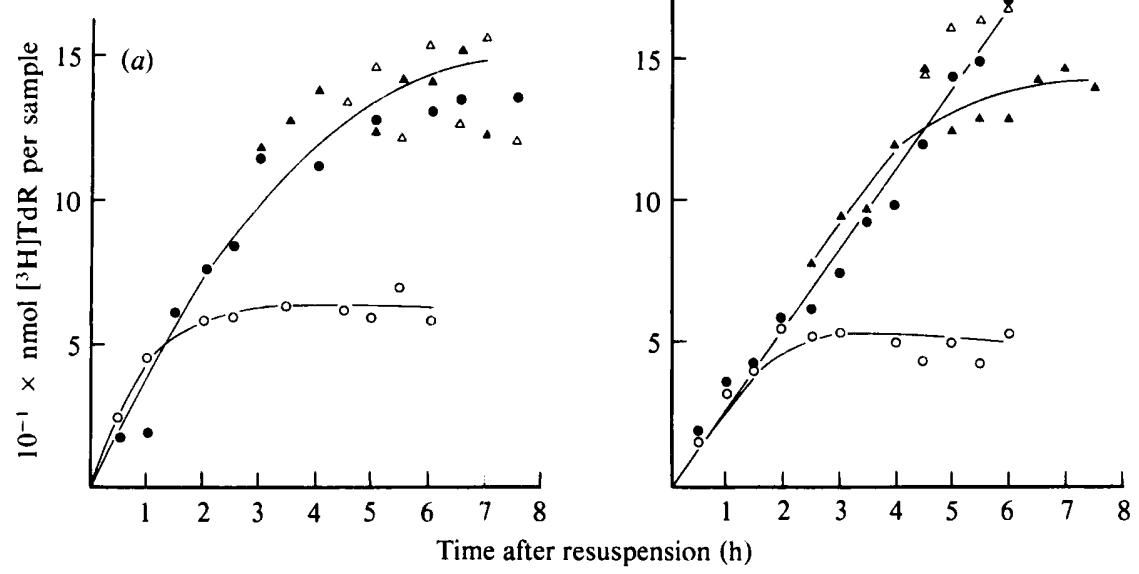

Fig. 3. Effect of chloramphenicol on DNA synthesis during sporulation of strain BUt32. (a) Cells were grown in $50 \mathrm{ml} \mathrm{CH}+\mathrm{TdR}\left(1 \mu \mathrm{g} \mathrm{ml}^{-1}\right)$ and resuspended in $\mathrm{SM}+\mathrm{TdR}\left(1 \mu \mathrm{g} \mathrm{ml}^{-1}\right)+\left[\right.$ methyl- $\left.{ }^{3} \mathrm{H}\right] \mathrm{TdR}$ $\left(0.5 \mu \mathrm{Ci} \mathrm{m}^{-1}\right)$. Immediately $(O)$ and at $2 \mathrm{~h}(\boldsymbol{\Delta})$ and $4 \mathrm{~h}(\triangle) 10 \mathrm{ml}$ samples were removed from the culture and treated with chloramphenicol $\left(100 \mu \mathrm{g} \mathrm{ml}^{-1}\right)$. The remainder of the culture was incubated without chloramphenicol (O). (b) A parallel culture was grown in $50 \mathrm{ml} \mathrm{CH}+\mathrm{TdR}\left(1 \mu \mathrm{g} \mathrm{ml}^{-1}\right)$ and resuspended in $\mathrm{SM}+\mathrm{TdR}\left(1 \mu \mathrm{g} \mathrm{ml}^{-1}\right)+\operatorname{BUdR}\left(15 \mu \mathrm{g} \mathrm{m}^{-1}\right)+\left[\right.$ methyl $\left.{ }^{3} \mathrm{H}\right] \mathrm{TdR}\left(0 \cdot 5 \mu \mathrm{Ci} \mathrm{m} l^{-1}\right)$. Samples were treated with chloramphenicol as above.

beyond $6 \mathrm{~h}$. These results indicated that, as with cells sporulating with $T d R$ alone, most cells initiated a round of replication between 0 and $2 \mathrm{~h}$ after resuspension and this was prevented by chloramphenicol. In addition, further replication was apparently initiated between 2 and $4 \mathrm{~h}$ after resuspension and this was prevented by the drug added at $2 \mathrm{~h}$.

\section{Marker frequency analysis of cells with synchronized DNA replication}

Marker frequency analysis was used in an attempt to analyse further the continued DNA synthesis in the presence of BUdR. The purA16 marker is located near the origin of replication and the metB5 marker near the terminus. The ratio of the numbers of transformants for these two markers will give an indication of the average number of replicating positions per chromosome (Sueoka \& Yoshikawa, 1965). DNA replication was synchronized in the cell population before exposure to $\mathrm{SM}$ by using a BUdR-tolerant derivative of a strain which is temperature-sensitive for the initiation of DNA replication. At $35^{\circ} \mathrm{C}$ the dnaB 134 but-32 strain (see Methods) grew with a doubling time of $66 \mathrm{~min}$ in both $\mathrm{CH}+\mathrm{TdR}\left(8.5 \mu \mathrm{g} \mathrm{ml}^{-1}\right)$ and $\mathrm{CH}+$ $\operatorname{TdR}\left(1 \mu \mathrm{g} \mathrm{ml}^{-1}\right)+\mathrm{BUdR}\left(15 \mu \mathrm{g} \mathrm{ml}^{-1}\right)$. The slow growth rate compared with the but-32 strain (doubling time $45 \mathrm{~min}$ ) was due to the $d n a B 134$ mutation as the parent dnaB134 strain also grew with a 66 min doubling time in $\mathrm{CH}+\mathrm{TdR}\left(8.5 \mu \mathrm{g} \mathrm{ml}^{-1}\right)$. However, in $\mathrm{CH}+\mathrm{TdR}\left(1 \mu \mathrm{g} \mathrm{ml}^{-1}\right)$ $+\operatorname{BUdR}\left(15 \mu \mathrm{g} \mathrm{ml}^{-1}\right)$ the parent dnaB134 strain grew only very poorly (doubling time $>240 \mathrm{~min}$ ).

DNA replication was synchronized by shifting cells growing exponentially at $35^{\circ} \mathrm{C}$ to $46^{\circ} \mathrm{C}$ for $75 \mathrm{~min}$. This allowed existing rounds of replication to terminate while at the same time preventing initiation of new rounds. A shift back to $35^{\circ} \mathrm{C}$ was accomplished by addition of an equal volume of growth medium held at room temperature. This simultaneously reduced the temperature and halved the bacterial density. DNA replication was then allowed to initiate in a synchronous manner on continued incubation at $35^{\circ} \mathrm{C}$. At the end of the $75 \mathrm{~min}$ period at $46^{\circ} \mathrm{C}$, DNA synthesis had slowed markedly and the $\mathrm{Pur}^{+} / \mathrm{Met}^{+}$ratio of the DNA had essentially halved (Fig. 4). Returning the cells to $35^{\circ} \mathrm{C}$ allowed DNA synthesis to restart and by $45 \mathrm{~min}$ the $\mathrm{Pur}^{+} / \mathrm{Met}^{+}$ratio had increased to a value similar to that found in cells before exposure to $46{ }^{\circ} \mathrm{C}$. 


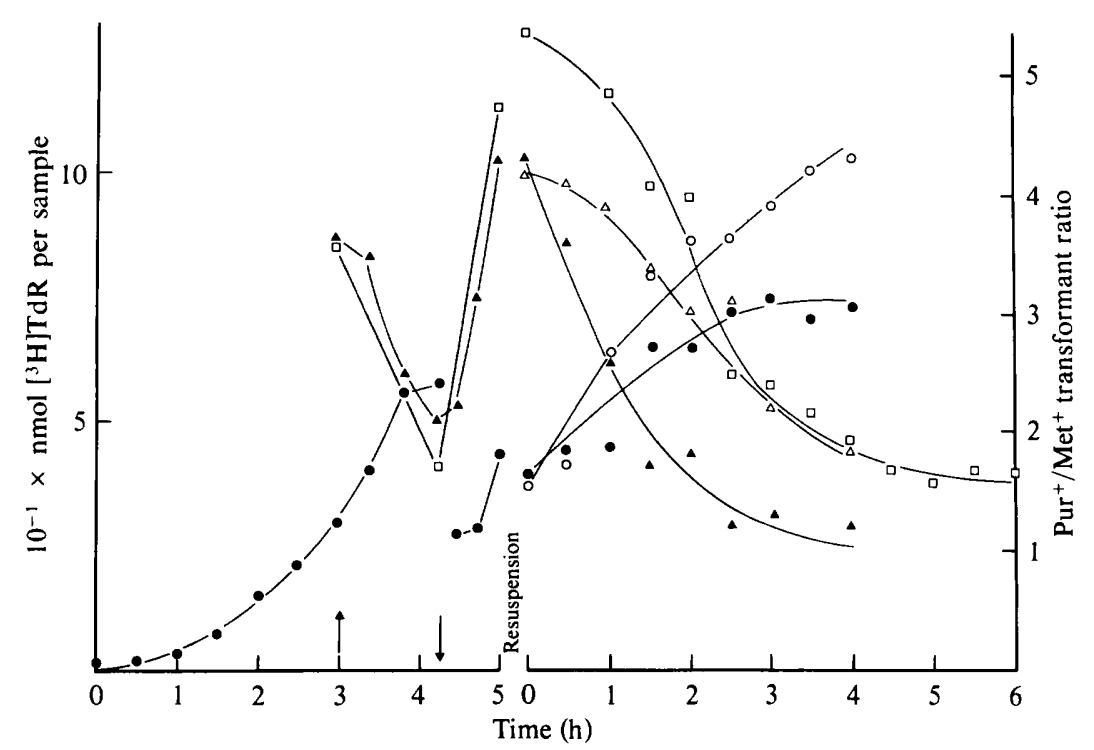

Fig. 4. DNA synthesis and marker frequency analysis during synchronization of replication and subsequent sporulation in strain dnaBl34 but-32. Cells were grown at $35^{\circ} \mathrm{C}$ in $\mathrm{CH}+\mathrm{TdR}\left(8.5 \mu \mathrm{g} \mathrm{ml}^{-1}\right)$ $+\left[\right.$ methyl $\left.l^{-3} \mathrm{H}\right] \mathrm{TdR}\left(0.5 \mu \mathrm{Ci} \mathrm{ml}{ }^{-1}\right)$ to an $\mathrm{OD}_{600}$ of 0.2 . They were then shifted to $46^{\circ} \mathrm{C}(\uparrow)$ for $75 \mathrm{~min}$. At the end of this time $(\downarrow)$ an equal volume of the same medium held at room temperature was added and incubation continued for a further $45 \mathrm{~min}$ at $35^{\circ} \mathrm{C}$. One half of the culture was then resuspended in SM $+\operatorname{TdR}\left(8.5 \mu \mathrm{g} \mathrm{ml}^{-1}\right)+\left[\right.$ methyl- $\left.{ }^{-3} \mathrm{H}\right] \mathrm{TdR}\left(0.5 \mu \mathrm{Ci} \mathrm{ml}^{-1}\right)(\boldsymbol{O}, \Delta)$ and the other half in SM $+\mathrm{TdR}$ $\left(1 \mu \mathrm{g} \mathrm{ml}^{-1}\right)+\operatorname{BUdR}\left(15 \mu \mathrm{g} \mathrm{ml}^{-1}\right)+\left[\right.$ methyl $\left.{ }^{3} \mathrm{H}\right] \mathrm{TdR}\left(0.5 \mu \mathrm{Ci} \mathrm{ml}^{-1}\right)(\bigcirc, \triangle, \square)$. Samples $(0 \cdot 2 \mathrm{ml})$ were taken for measurement of incorporation of radiolabelled TdR into acid-insoluble material $(O, O)$ and other samples $(10 \mathrm{ml})$ taken for preparation of DNA and transformation of strain Mu8u5ul6 (purA16 leu-8 metB5) $(\Delta, \triangle)$. In a separate experiment, cells were resuspended in $\mathrm{TdR}\left(1 \mu \mathrm{g} \mathrm{ml}^{-1}\right)+$ BUdR $\left(15 \mu \mathrm{g} \mathrm{ml}^{-1}\right)$ and samples taken for transformation only $(\square)$. Transformation was done in triplicate for each DNA preparation and at least 200 transformants were counted in each transformation experiment. The Mean $\mathrm{Pur}^{+} / \mathrm{Met}^{+}$ratios were standardized with respect to the $\mathrm{Pur}^{+} / \mathrm{Met}^{+}$ratio obtained from spore DNA (see the accompanying paper; Coote \& Binnie, 1986).

Preliminary experiments using the parent $d n a B 134$ strain had confirmed an earlier observation (Mandelstam et al., 1971) that cells allowed to complete replication at the restrictive temperature were then unable to reinitiate new rounds in $\mathrm{SM}$ at $35^{\circ} \mathrm{C}$ and were unable to sporulate. It was therefore necessary to allow cells to reinitiate replication in the rich $\mathrm{CH}$ medium for a $45 \mathrm{~min}$ period before exposure to SM to induce sporulation.

Cells induced to sporulate in $\mathrm{SM}+\mathrm{TdR}$, after synchronization of DNA replication, showed a rapid decrease in the $\mathrm{Pur}^{+} / \mathrm{Met}^{+}$ratio which reached a plateau value of 1.2 some $3 \mathrm{~h}$ after resuspension in SM; DNA synthesis had also ceased by this time (Fig. 4). Taken together, these observations indicated that most cells had terminated replication by this time and had formed completed chromosomes. Cells resuspended in the presence of BUdR exhibited a slower fall in the Pur ${ }^{+} / \mathrm{Met}^{+}$ratio of their DNA (Fig. 4). In the experiment where BUdR-treated cells were compared with cells given $T d R$ alone, a plateau value had not been reached by the time the experiment was terminated, $4 \mathrm{~h}$ after resuspension. DNA synthesis had also not ceased by this time (Fig. 4). In a separate experiment involving only cells exposed to BUdR, an apparent plateau value of 1.7 was reached some $5 \mathrm{~h}$ after resuspension. This indicated that even by this time not all the cells in the population had terminated replication.

\section{DISCUSSION}

Density gradient analysis, where BUdR was used as a density label, had shown that DNA substituted in both strands with BUdR (HH DNA) was excluded from the DNA found in the 
low number of spores formed in the presence of the analogue (Binnie \& Coote, 1983). It was suggested that heavy DNA containing BUdR in both strands was for some physiological reason unsuitable for incorporation into spores. This interpretation is supported by the observation reported here that cells required between 60 and $90 \mathrm{~min}$ of DNA synthesis in the absence of BUdR before they regained the capacity to sporulate. The chromosome replication time of strain BUt32 in TdR medium was calculated to be $70 \mathrm{~min}$ (Coote \& Binnie, 1986), and so the time needed for recovery from BUdR inhibition of sporulation would be sufficient for one complete round of replication. This would create DNA of intermediate density (HL DNA), with BUdR in only one strand, which can be packaged satisfactorily into spores (Binnie \& Coote, 1983).

BUdR only inhibited sporulation in strain BUt32 if it was added at least $15 \mathrm{~min}$ before cells terminated DNA replication during the initial stages of the process (Coote \& Binnie, 1981; Fig. 2). The density gradient analysis had indicated that HH DNA could not be incorporated into spores, but this did not explain why the analogue could prevent sporulation right up to a point shortly before termination of replication. In such a case, only a small portion of one strand of the chromosome near the terminus region would incorporate the analogue. Yet density gradient analysis showed that intermediate density DNA could be incorporated normally into spores (Binnie \& Coote, 1983). This raised the possibility that BUdR acted to reinitiate rounds of replication at the origin. In the starvation medium, this would have the effect of prolonging DNA replication and the formation of completed chromosomes to an extent that might prevent normal packaging of DNA into the spores. It would be in keeping with the prolonged DNA synthesis observed in cells induced to sporulate in the presence of the analogue. Chloramphenicol treatment of cells sporulating with $\mathrm{TdR}$ alone indicated that most cells initiated a round of replication between 0 and $2 \mathrm{~h}$ after resuspension, and that thereafter replication proceeded to completion without further initiation at the origin. Cells sporulating with BUdR, however, appeared to initiate at least one further round of replication between 2 and $4 \mathrm{~h}$ after resuspension. Examination of chromosome replication by marker frequency analysis also indicated that cells took longer to terminate replication in the presence of the analogue.

We conclude that the delay in termination of replication exhibited by cells induced to sporulate with BUdR is due to a slowing down in the rate of replication coupled with unscheduled initiation of replication at the origin. This would have two effects. First, it would prevent unforked, completed chromosomes being made available to cells for incorporation into spores. Second, further initiation of DNA replication at the origin would give rise to heavy DNA, substituted in both strands with BUdR, in those cells where initiation of replication had already taken place in the starvation medium. Heavy DNA, although representing a major fraction of DNA isolated from cells in SM + BUdR, was nevertheless excluded from the few spores formed in the presence of the analogue (Binnie \& Coote, 1983). Whether only one of these two consequences of BUdR action, or whether both combined, result in the inhibition of spore formation remains to be clarified.

We thank M. Achison for excellent technical assistance. The work was supported by the Science and Engineering Research Council and a University of Glasgow postgraduate scholarship.

\section{REFERENCES}

BINNIE, C. (1982). The effect of 5-bromo-2'-deoxyuridine on growth and sporulation in Bacillus subtilis. $\mathrm{PhD}$ thesis, University of Glasgow, UK.

Binnie, C. \& Coote, J. G. (1983). Density gradient analysis of DNA replicated during Bacillus subtilis sporulation. Journal of Bacteriology 156, 466-470.

Biswas, D. K., Abdullah, K. T. \& Brennessel, B. A. (1979). On the mechanism of 5-bromodeoxyuridine induction of prolactin synthesis in rat pituitary tumor cells. Journal of Cell Biology 81, 1-19.
Brown, N. C. (1970). 6-( $p$-Hydroxyphenylazo)-uracil: a selective inhibitor of host DNA replication in phage-infected Bacillus subtilis. Proceedings of the National Academy of Sciences of the United States of America 67, 1451-1461.

Brown, N. C. (1971). Inhibition of bacterial DNA replication by 6-( $p$-hydroxyphenylazo)-uracil : differential effect on repair and semi-conservative synthesis in Bacillus subtilis. Journal of Molecular Biology 59, 1-16. 
Conway, W. F., Schwartz, N. B. \& Dorfman, A. (1982). The irreversible effect of bromodeoxyuridine on chick chondrocytes. Experimental Cell Research 139, 79-86.

COOTE, J. G. (1977). Interference by bromodeoxyuridine with differentiation in a prokaryote. Nature, London 267, 635-637.

CoOTE, J. G. \& BinNie, C. (1981). Association between DNA replication and interference by bromodeoxyuridine with sporulation in Bacillus subtilis. In Sporulation and Germination, pp. 157-162. Edited by H. S. Levinson, A. L. Sonenshein \& D. J. Tipper. Washington, DC: American Society for Microbiology.

COOTE, J. G. \& BINNIE, C. (1986). Tolerance to bromodeoxyuridine in a thymidine-requiring strain of Bacillus subtilis. Journal of General Microbiology 132, 481-492.

Davidson, R. L. \& Kaufmann, E. R. (1977). Deoxycytidine reverses the suppression of pigmentation caused by 5-BrdUrd without changing the amount of 5-BrdUrd in DNA. Cell 12, 923-929.

DunN, G., JefFs, P., MANN, N. H., TORgERSEN, D. M. \& YounG, M. (1978). The relationship between DNA replication and the induction of sporulation in Bacillus subtilis. Journal of General Microbiology 108 , 189-195.

Evans, I., Distefano, P., Case, K. R. \& Bosmann, H. B. (1977). Cell surface changes caused by growth of B16 melanoma cells in bromodeoxyuridine. FEBS Letters 78, 109-112.

Garcia, M., Westley, B. \& Rochefort, H. (1981). 5Bromodeoxyuridine specifically inhibits the synthesis of estrogen-induced proteins in $\mathrm{MCF}_{7}$ cells. European Journal of Biochemistry 116, 297-301.

Gordon, J. S., Bell, G. I., Martinson, H. C. \& RUTTER, W. J. (1976). Selective interaction of 5 ' bromo-deoxyuridine substituted DNA with different chromosomal proteins. Biochemistry 15, 4778 4786.

Hill, B. T., Tsuboi, A. \& Baserga, R. (1974). Effect of 5-bromodeoxyuridine on chromatin transcription in confluent fibroblasts. Proceedings of the National Academy of Sciences of the United States of America 71, 455-459.

HORN, D. \& DAVIDSON, R. L. (1976). Inhibition of biological effects of bromodeoxyuridine by deoxycytidine: correlation with decreased incorporation of bromodeoxyuridine into DNA. Somatic Cell Genetics 2, 469-481.

Hutchinson, F. \& Hales, H. B. (1970). Mechanism of the sensitisation of bacterial transforming DNA to ultraviolet light by the incorporation of 5-bromouracil. Journal of Molecular Biology 50, 59-69.

Johnson, W. C., Moran, C. P. \& Losick, R. (1983). Two RNA polymerase sigma factors from Bacillus subtilis discriminate between overlapping promoters for a developmentally regulated gene. Nature, London 302, 800-804.

Koyama, H. \& ONO, T. (1972). Further studies on the induction of alkaline phosphatase by 5-bromodeoxyuridine in a hybrid line between mouse and Chinese hamster in culture. Biochimica et biophysica acta 264, 497-507.

LaRK, K. G., REPKo, T. \& Hoffan, E. J. (1963). The effect of amino acid deprivation on subsequent deoxyribonucleic acid replication. Biochimica et biophysica acta 76, 9-24.

LevitT, D. \& DoRfman, A. (1972). The irreversible inhibition of differentiation of limb-bud mesenchyme by bromodeoxyuridine. Proceedings of the National Academy of Sciences of the United States of America 69, 1253-1257.

LiN, S., LIN, D. \& RigGs, A. D. (1976). Histones bind more tightly to bromodeoxyuridine-substituted DNA than to normal DNA. Nucleic Acids Research 3, 2183-2191.

Losick, R. \& Pero, J. (1981). Cascades of sigma factors. Cell 25, 582-584.

Lough, J. \& Bischoff, R. (1976). Differential sensitivity to 5-bromodeoxyuridine during the S-phase of synchronised myogenic cells. Developmental Biology 50, 457-475.

Mandelstam, J., Sterlini, J. M. \& Kay, D. (1971). Sporulation of Bacillus subtilis. Effect of medium on the form of chromosome replication and on initiation of sporulation in Bacillus subtilis. Biochemical Journal 125, 635-641.

MAYNe, R., ABbot, J. \& Holtzer, H. (1973). Requirement for cell proliferation for the effects of 5-bromodeoxyuridine on cultures of chick chondrocytes. Experimental Cell Research 77, 255-263.

Mendelson, N. H. \& Gross, J. D. (1967). Characterisation of a temperature-sensitive mutant of Bacillus subtilis defective in deoxyribonucleic replication. Journal of Bacteriology 94, 1603-1608.

MiURA, Y. \& WILT, F. H. (1971). The effects of bromodeoxyuridine on yolk sac erythropoiesis in the chick embryo. Journal of Cell Biology 48, 523532.

O'BRIEN, J. C. (1980). Tyrosine aminotransferase sensitivity to bromodeoxyuridine during restricted intervals of S-phase in Hepatoma cells. Journal of Cell Biology 87, 629-632.

Oishi, M., Yoshikawa, H. \& Sueoka, N. (1964). Synchronous and dichotomous replications of the Bacillus subtilis chromosome during spore germination. Nature, London 204, 1069-1073.

Piggot, P. J. \& Coote, J. G. (1976). Genetic aspects of bacterial endospore formation. Bacteriological Reviews 40, 908-962.

RefF, M. E. \& Davidson, R. C. (1979). Deoxycytidine reverses the suppression of pigmentation caused by 5-BrdUrd without changing the distribution of 5BrdUrd in DNA. Journal of Biological Chemistry 254, 6869-6872.

Rima, B. K. \& TaKahashi, I. (1978). Synthesis of thymidine nucleotides in Bacillus subtilis. Canadian Journal of Biochemistry 56, 158-160.

Rogers, J., NG., S. K. C., Coulter, M. B. \& Sanwal, B. D. (1975). Inhibition of myogenesis in a rat myoblast line by 5-bromodeoxyuridine. Nature, London 256, 438-440.

Rosenthal, S. L., Parola, A. H., Blout, E. R. \& DAvidson, R. L. (1978). Membrane alterations associated with "transformation" by BUdR in BUdR-dependent cells. Experimental Cell Research 112, 419-429.

Rutter, W. J., PiCtet, R. C. \& Morris, P. W. (1973). Toward molecular mechanisms of development processes. Annual Review of Biochemistry 42, 601646 . 
SARGENT, M. G. (1980). Chromosome replication in sporulating cells of Bacillus subtilis. Journal of Bacteriology 142, 491-498.

SChUBERT, D. \& JaCOB, F. (1970), 5-Bromodeoxyuridine induced differentiation of a neuroblastoma. Proceedings of the National Academy of Sciences of the United State's of America 67, 246-254.

Sterlini, J. M. \& Mandelstam, J. (1969). Commitment to sporulation in Bacillus subtilis and its relationship to development of actinomycin resistance. Biochemical Journal 113, 29-37.
Stockdale, F., OKazaki, K., Nameroff, M. \& Holtzer, H. (1964). 5-Bromodeoxyuridine: effect on myogenesis in vitro. Science 146, 533-535.

Sueoka, N. \& Yoshikawa, H. (1965). The chromosome of Bacillus subtilis. I. Theory of marker frequency analysis. Genetics 52, 747-757.

Weintraub, H., Campbell, G. L. \& Holtzer, H. (1972). Identification of a developmental program using bromodeoxyuridine. Journal of Molecular Biology 70, 337-350. 